\title{
Analysis of Karnal Bunt and Black Point of Wheat in Tarn Taran District of Punjab, India
}

\author{
Parminder Kaur $^{1 *}$, Paramjit Singh ${ }^{2}$ and Amarjit Singh ${ }^{3}$ \\ ${ }^{1}$ Farm Advisory Service Centre, Tarn Taran -143401, Punjab, India \\ ${ }^{2}$ Regional Research Station, Kapurthala -144601, Punjab, India \\ ${ }^{3}$ Punjab Agricultural University, Ludhiana- 141004, Punjab, India \\ *Corresponding author
}

\section{Keywords}

Wheat, Karnal Bunt, Black point, Disease prevalence, Disease incidence

Article Info

Accepted:

05April 2020

Available Online:

10 May 2020

\begin{abstract}
A B S T R A C T
Wheat is an important cereal crop grown all over the world. There are many abiotic and biotic stresses which affects the yield of the crop. Out of this, diseases are the principal cause which is responsible for the decrease in yield. Karnal Bunt is the major disease which affects quality of food grain. Black Point is also becoming a serious problem in Punjab. The analysis of 140 grain samples collected from different grain markets of 8 blocks of Tarn Taran district in Punjab was conducted during 2018-2019. It was found that Karnal Bunt and Black Point disease was prevalent in all blocks. 86 and 80 samples of wheat were infected with Karnal Bunt and Black Point disease respectively. The prevalence of Karnal Bunt was more (92.30\%) in Chohla Sahib block and Black Point was more prevalent in Valtoha (76.47\%). The mean range of infection was more in Naushera Pannuan block $(0.0-12.7 \%)$ and Black Point was in Chohla Sahib block $(0.0-2.3 \%)$. The disease incidence was correlated with the favourable climatic conditions during the heading stage of the crop. For determination of varietal variation it was found that Karnal Bunt incidence was more in HD 2967 $(0.1-12.7 \%)$ in Naushera Pannuan block and Black Point gave maximum range of infection in HD 3086 in Bhikhiwind block. The disease incidence in recommended varieties was negligible. So, farmers were advised to grow recommended varieties of PAU which are suitable in Punjab agroclimatic conditions. In future regular surveys would be encouraged to identify the tolerant varieties which are grown in different blocks of Tarn Taran district of Punjab.
\end{abstract}

\section{Introduction}

Wheat (Triticum aestivum) is an important food crop for majority of the world's population. India is the second largest producer of wheat in the world after China (Sharma et al., 2016) whereas in India, Punjab is the major wheat producing State. It is cultivated on an area of 35.12 lakh hectares with 178.30 lakh tonnes of production and 50.77 quintals per hectare of average yield during 2017-18 (Anon, 2019). There are several constraints for low productivity of wheat in Punjab.

Significant yield losses are reported due to different biotic and abiotic stresses in Punjab. Among these factors, diseases are the major 
causes which are responsible for low yield in wheat. The most damaging diseases are Yellow Rust, Loose Smut, Karnal Bunt, Black Point and Powdery mildew. Out of these Karnal Bunt and Black Point are most dangerous diseases which affect the quality of the grains.

Karnal Bunt (Tilletia indica) is seed and soil borne in nature. It may attack on whole earhead as well as on the part of the earhead. It replaces part of the seed with black powdery mass which emits foul smell due to the presence of the volatile chemical trimethyline (Singh et al., 1993). It was first reported in Karnal by Mitra in 1931. It is regarded as disease of quarantine importance and causes serious losses every year (Asma et al., 2012). During severe epidemic period, total losses have been reported approximately 0.3 to 0.5 per cent with disease incidence of 89 per cent in some fields (Joshi et al., 1983).

The incidence depends upon favourable weather conditions during heading stage as it affects the heads of wheat. It was reported that the initial infection occurs when there is cool weather and temperature ranges between $20-25^{\circ} \mathrm{C}$ alongwith high relative humidity (Asma et al., 2012). It reduces yield and also result in flour having an objectionable fishy odour, colour, and taste thus reducing the quality of the flour (Aujla, et al., 1980).

Black Point is also becoming an emerging problem in wheat and it is associated with many fungi like Alternaria alternata, Cladosporium cladosporoides, Bipolaris sorokiniana, Curvularia lunata, Fusarium and Helminthosporium spp. (Watkin, 2005,
Jain et al., 2012, Jaspal et al., 2018). Both the diseases causes disclouration of grains, reduces grain quality and lowers the market price of the commodity. Keeping in view, its great significance, the present study was attempted for the analysis of Karnal Bunt and Black Point to identify the disease free areas and resistant wheat varieties grown in Tarn Taran district of Punjab.

\section{Materials and Methods}

The different grain markets were visited during Rabi season 2018-2019. 140 grain samples each of $250 \mathrm{gm}$ of different Wheat varieties were collected during field visits from 8 blocks of districts i.e, Naushera Pannuan, Tarn Taran, Patti, Bhikhiwind, Khadur Sahib, Chohla Sahib, Chabhal and Valtoha. The samples were collected in labelled polythene bags indicating name of the farmer, location, grain market, variety sown and other parameters etc. Samples were collected randomly from 4 to 5 stacks of different farmers and then samples were brought to the laboratory for further investigation.

1000 seeds were taken from each sample for visual observation under stereoscopic binocular microscope for diseased and healthy seeds. Healthy seeds were identified as smooth coat and brown in colour whereas infected seeds are small, wrinkled and with black powdery mass. The seeds were poured in the tray having white sheet for easy identification of the infected grains. Disease prevalence was calculated from samples in different blocks of the district by using formula

$$
\text { Disease prevalence }(\%)=\frac{\text { No. of disease samples in block }}{\text { Total no. of samples in a block }} \times 100
$$


Per cent incidence of Karnal Bunt infection from each sample was calculated by using the formula

$$
\text { Karnal Bunt incidence }(\%)=\frac{\text { No. of Infected grains }}{\text { Total no. of grains }}
$$

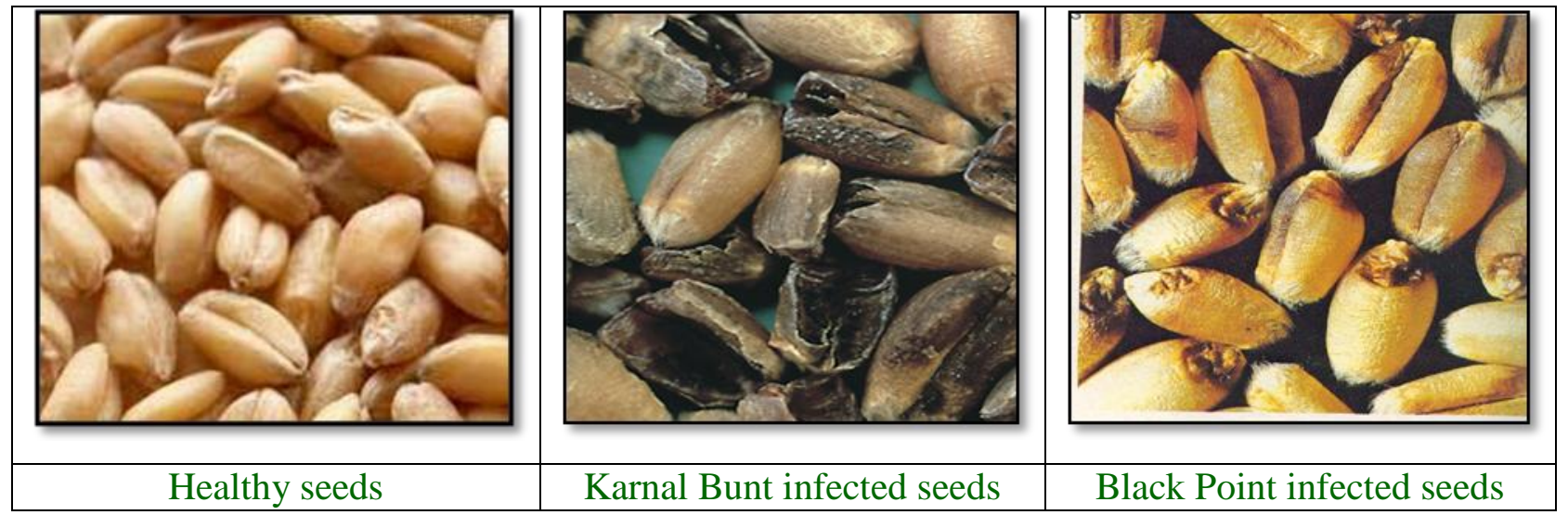

\section{Results and Discussion}

Karnal Bunt is an important quarantine disease and now it is considered as a common disease in Punjab region. The survey was conducted in 10 grain markets of 8 blocks of the District during 2018-2019. The total 140 samples were collected which were further analysed for Karnal Bunt and Black Point infection (Table 1). It was predicted that Karnal Bunt disease was prevalent in all the grain markets of the district and no grain market was found to be free from Karnal Bunt infection. Out of 140 samples, 86 samples were infected with Karnal Bunt and 80 samples had an infection of Black Point disease.

It was revealed from the Table 2 and Figure 2 that the maximum disease prevalence of Karnal Bunt was observed in Chohla Sahib block (92.30\%) followed by Naushera Pannuan (76.47\%) and Gandiwind (72.72\%) whereas lowest in block Bhikhiwind (51.61\%). The highest Karnal Bunt infection was found in Naushera Pannuan block with range of $0.0-12.7 \%$ and lowest in Gandiwind with range of infection $0.0-0.3 \%$. The reason behind the prevalence and incidence could be due to favourable weather conditions including low temperature, high rainfall, more no. of rainy days and high humidity during February to March when the crop was at heading stage (Sharma et al., 2012, Kaur et al., 2018).

Black Point is becoming an emerging problem day by day. It was present in all the wheat growing states (Singh et al., 2003). Prevalence of Black Point was observed in different wheat varieties. The disease prevalence was maximum in Valtoha (76.47\%) and lowest in Naushera Pannuan (35.29\%) (Fig 2 and Table 4). Whereas, the lowest range of infection i.e. 0.0-0.5 \% was found in the samples collected from the grain markets of Patti and Valtoha blocks. The highest range was found in the Chohla Sahib block (0.0-2.3 \%) (Table 4). Singh et al., 2003 revealed that Black Point was more prevalent in warmers regions that hills. Its incidence was reported regularly since 2007-2008 to 2010- 2011 by Jain et al., 2012. The reason for regular incidence of Black Point was also 
due to favourable weather conditions during 2018-2019 in Tarn Taran District. Its incidence varied with the amount of rainfall and low temperature with high humidity (Table 3). For determination of varietal difference, nine (9) different wheat varieties whose samples were collected namely Unnat PBW 343, PBW 725, HD 3086, HD 2967, PBW 677, Unnat PBW 550, WH 1105, PBW 658 and PBW 752 from blocks of Tarn Taran district during 2018-2019 were observed for Karnal Bunt and Black Point infection.

In Bhikhiwind block it was revealed that out of 05 prevalent cultivars, highest range of disease incidence was observed on variety HD 3086 (0.0 -10.6\%) whereas no incidence was reported from Unnat PBW 343 and PBW 677. Whereas HD 2967 and PBW 725 reported range of infection as $0.0-0.5 \%$ and $0.2 \%$ respectively. 4 varieties namely Unnat PBW 343, HD 3086, HD 2967 and Unnat PBW 550 were commonly prevalent varieties were examined in Gandiwind block. 0.0-0.2\% and $0.0-0.3 \%$ range of infection was observed in HD 3086 and HD 2967 varieties respectively whereas $0.1 \%$ infection was reported in both Unnat PBW 343 and Unnat PBW 550 cultivars.

Patti block demonstrated no disease incidence in Unnat PBW 343, Unnat PBW 550 and PBW 677 varieties while $0.0-0.5 \%, 0.0-1.0 \%$ and $0.1 \%$ infection range was found in HD 2967, HD 3086 and PBW 725 respectively. 5 varieties were studied for percent disease infection due to Karnal Bunt in Valtoha in which $0.0-0.1 \%$ infection range was observed in Unnat PBW 343 and HD 2967 cultivars. Whereas $0.0-0.6 \%, 0.5 \%$ and $1.2 \%$ infection range was found in HD 3086, PBW 725 and WH 1105 respectively. Observations recorded in Naushera Pannuan about prevalently grown 7 varieties were Unnat PBW 343, Unnat PBW 550, PBW 725, PBW 658, PBW 752,
HD 3086, HD 2967. Highest range of infection (0.1-12.7\%) was observed in HD 2967. However in Unnat PBW 550 was found lowest disease infection range (0.0-0.7\%) and PBW 725 (0.0-0.6\%). No disease was observed in PBW 658 and PBW 752. 2 varieties HD 3086 and Unnat PBW 343 demonstrated $0.4-1.4 \%$ and $0.2-0.4 \%$ range of percent infection respectively.

Studies in Chohla Sahib block showed disease infection in Unnat PBW 550 (0.4\%), PBW 725 (0.4-8.6\%), HD 3086 (0.3-4.9\%) and HD 2967 (0.4-1.1\%) respectively. In Tarn Taran block, WH 1105 showed maximum range of disease incidence $(0.0-3.7 \%)$. The other varieties have disease incidence upto $0.8 \%$. Khadur Sahib had maximum disease incidence of $5.4 \%$ in Unnat PBW 343 followed by $4.2 \%$ in Unnat PBW 550, 0.0$3.8 \%$ in WH 1105, $2.0 \%$ in PBW 725, 0.0$1.5 \%$ in HD 3086 and HD 2967 was found to be free from Karnal Bunt infection (Table 5).

Similarly, Black Point incidence was also observed in all the varieties in which maximum incidence was found in HD 3086 (0.0-1.7\%) in Bhikhiwind block followed by $0.8 \%$ in Unnat PBW 343 in Khadur Sahib, 0,0- 0.7\% in HD 3086 and HD 2967 of Naushera Pannuan and Chohla Sahib blocks respectively. In Gandiwind and Tarn Taran blocks, disease incidence was $0.0-0.6 \%$ in HD 2967 and WH 1105 varieties. Patti and Valtoha blocks have incidence upto $0.5 \%$ in HD 3086 varieties (Table 5).

It was concluded from the results that Karnal Bunt and Black Point incidence was less in recommended varieties of PAU i.e Unnat PBW 343 and Unnat PBW 550 showed resistance in all the blocks except in Khadur Sahib. PBW 725 performed well in all 7 blocks except is Chohla Sahib block. 
Table.1 Detail of different grain markets of Tarn Taran district of Punjab from where samples of wheat were collected during 2018-2019

\begin{tabular}{|l|c|c|c|l|}
\hline Blocks & $\begin{array}{c}\text { Total } \\
\text { samples }\end{array}$ & $\begin{array}{c}\text { Infected samples } \\
(\mathbf{K B})\end{array}$ & $\begin{array}{c}\text { Infected samples } \\
(\mathbf{B P})\end{array}$ & Grain market \\
\hline Bhikhiwind & 31 & 16 & 19 & Chabhal, Bhikhiwind \\
\hline Gandiwind & 11 & 7 & 7 & Gaggobua \\
\hline Patti & 15 & 8 & 7 & Patti \\
\hline Valtoha & 17 & 9 & 13 & Algon Kothi, Amarkot \\
\hline Naushera Pannuan & 17 & 13 & 6 & Naushera Pannuan \\
\hline Chohla Sahib & 13 & 12 & 8 & Chohla Sahib \\
\hline Tarn Taran & 27 & 16 & 15 & TarnTaran \\
\hline Khadur Sahib & 9 & 5 & 5 & Khadur Sahib \\
\hline Total Samples & $\mathbf{1 4 0}$ & $\mathbf{8 6}$ & $\mathbf{8 0}$ & \\
\hline
\end{tabular}

Table.2 Per cent Karnal Bunt infection in different blocks of Tarn Taran District during 2018-2019

\begin{tabular}{|l|c|c|}
\hline Blocks & Prevalence KB (\%) & Mean range of infection KB (\%) \\
\hline Bhikhiwind & 51.61 & $0.0-10.6$ \\
\hline Gandiwind & 72.72 & $0.0-0.3$ \\
\hline Patti & 53.53 & $0.0-1.0$ \\
\hline Valtoha & 52.94 & $0.0-0.6$ \\
\hline Naushera Pannuan & 76.47 & $\mathbf{0 . 0}-12.7$ \\
\hline Chohla Sahib & $\mathbf{9 2 . 3 0}$ & $0.0-8.6$ \\
\hline TarnTaran & 59.25 & $0.0-3.8$ \\
\hline Khadur Sahib & 55.55 & $0.0-5.4$ \\
\hline
\end{tabular}

Table.3 Weather parameters during February to March, 2019 in Tarn Taran district of Punjab

\begin{tabular}{|l|c|c|c|c|c|c|c|}
\hline $\begin{array}{l}\text { Month } \\
\text { (Year) }\end{array}$ & $\begin{array}{c}\text { Total } \\
\text { rainfall }\end{array}$ & $\begin{array}{c}\text { No. of rainy } \\
\text { days }\end{array}$ & $\begin{array}{c}\text { Max. Temp } \\
\text { (C) }^{\mathbf{0}}\end{array}$ & $\begin{array}{c}\text { Min. } \\
\text { Temp(C) }\end{array}$ & Humidity* & KB \% & BP \% \\
\hline February, 2019 & 467.1 & 8 & 19.57 & 7.25 & 81 & 0.821 & 0.206 \\
\hline March, 2019 & 7.10 & 2 & 24.64 & 10.38 & 67 & & \\
\hline
\end{tabular}

Source : https://www.accuweather.com/en/in/tarn-taran/

* https://www.timeanddate.com/weather/india/tarn-taran-sahib/

Table.4 Per cent Black Point infection in different blocks of Tarn Taran district of

Punjab during 2018-2019

\begin{tabular}{|l|c|c|}
\hline Blocks & Prevalence BP $(\boldsymbol{\%})$ & Mean range of infection BP(\%) \\
\hline Bhikhiwind & 48.38 & $0.0-0.6$ \\
\hline Gandiwind & 63.63 & $0.0-0.6$ \\
\hline Patti & 46.66 & $0.0-0.5$ \\
\hline Valtoha & $\mathbf{7 6 . 4 7}$ & $0.0-0.5$ \\
\hline Naushera Pannuan & 35.29 & $0.0-0.7$ \\
\hline Chohla Sahib & 61.53 & $\mathbf{0 . 0}-2.3$ \\
\hline TarnTaran & 55.55 & $0.0-0.6$ \\
\hline Khadur Sahib & 55.55 & $0.0-1.3$ \\
\hline
\end{tabular}


Table.5 Percentage of Karnal Bunt and Black Point infected samples in different varieties of wheat during 2018-2019

\begin{tabular}{|c|c|c|c|}
\hline Blocks & Variety & $\begin{array}{c}\text { Mean range of infection } \\
\text { KB }(\%)\end{array}$ & $\begin{array}{c}\text { Mean range of infection } \\
\text { BP }(\%)\end{array}$ \\
\hline \multirow[t]{5}{*}{ Bhikhiwind } & Unnat PBW 343 & 0.0 & 0.0 \\
\hline & PBW 725 & 0.2 & 0.6 \\
\hline & HD 3086 & $0.0-10.6$ & 0.0-1.7 \\
\hline & HD 2967 & $0.0-0.5$ & $0.0-0.6$ \\
\hline & PBW 677 & 0.0 & 0.2 \\
\hline \multirow[t]{4}{*}{ Gandiwind } & Unnat PBW 343 & 0.1 & 0.0 \\
\hline & HD 3086 & $0.0-0.2$ & $0.0-0.4$ \\
\hline & HD 2967 & $0.0-0.3$ & $0.0-0.6$ \\
\hline & Unnat PBW 550 & 0.1 & 0.1 \\
\hline \multirow[t]{6}{*}{ Patti } & Unnat PBW 343 & 0.0 & 0.0 \\
\hline & PBW 725 & 0.1 & 0.1 \\
\hline & Unnat PBW 550 & 0.0 & 0.0 \\
\hline & PBW 677 & 0.0 & 0.3 \\
\hline & HD 3086 & $0.0-1.0$ & $0.0-0.5$ \\
\hline & HD 2967 & $0.0-0.5$ & $0.0-0.2$ \\
\hline \multirow[t]{5}{*}{ Valtoha } & Unnat PBW 343 & $0.0-0.1$ & $0.1-0.4$ \\
\hline & PBW 725 & 0.5 & 0.0 \\
\hline & WH 1105 & 1.2 & 0.3 \\
\hline & HD 3086 & $0.0-0.6$ & $0.1-0.5$ \\
\hline & HD 2967 & $0.0-0.1$ & $0.0-0.5$ \\
\hline \multirow[t]{7}{*}{ Naushera Pannuan } & Unnat PBW 343 & $0.2-0.4$ & 0.0 \\
\hline & Unnat PBW 550 & $0.0-0.7$ & $0.0-0.4$ \\
\hline & PBW 725 & $0.0-0.6$ & 0.0 \\
\hline & PBW 658 & 0.0 & 0.0 \\
\hline & PBW 752 & 0.0 & 0.0 \\
\hline & HD 3086 & $0.4-1.4$ & 0,0- 0.7 \\
\hline & HD 2967 & $0.1-12.7$ & $0.0-0.2$ \\
\hline \multirow[t]{4}{*}{ Chohla Sahib } & Unnat PBW 550 & 0.4 & 0.0 \\
\hline & PBW 725 & $0.4-8.6$ & $0.2-0.3$ \\
\hline & HD 3086 & $0.3-4.9$ & $0.0-0.4$ \\
\hline & HD 2967 & $0.4-1.1$ & $0.0-0.7$ \\
\hline \multirow[t]{7}{*}{ Tarn Taran } & Unnat PBW 343 & $0.2-0.3$ & $0.0-0.2$ \\
\hline & Unnat PBW 550 & 0.2 & 0.1 \\
\hline & PBW 725 & 0.0 & 0.4 \\
\hline & WH 1105 & $0.0-3.8$ & $0.0-0.6$ \\
\hline & PBW 677 & $0.0-0.1$ & 0.0 \\
\hline & HD 3086 & $0.0-0.3$ & $0.0-0.6$ \\
\hline & HD 2967 & $0.0-0.8$ & $0.0-0.4$ \\
\hline \multirow[t]{6}{*}{ Khadur Sahib } & Unnat PBW 343 & 5.4 & 0.8 \\
\hline & Unnat PBW 550 & 4.2 & 0.4 \\
\hline & PBW 725 & 2.0 & 0.0 \\
\hline & WH 1105 & $0.0-2.8$ & $0.0-0.4$ \\
\hline & HD 3086 & $0.0-1.5$ & $0.0-1.3$ \\
\hline & HD 2967 & 0.0 & $0.0-0.4$ \\
\hline
\end{tabular}




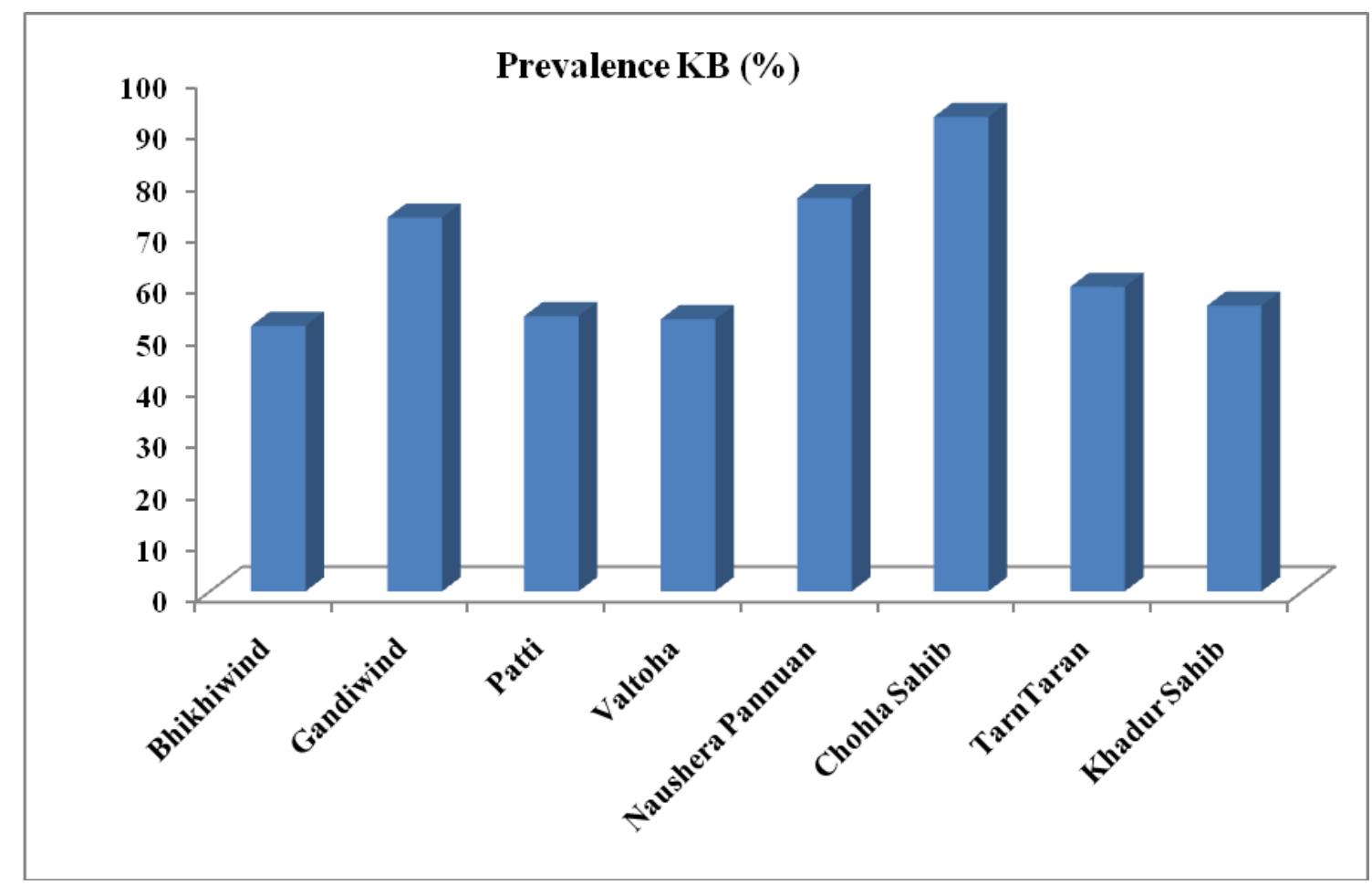

Fig.1 Prevalence of Karnal Bunt infection in different blocks of Tarn Taran district of Punjab

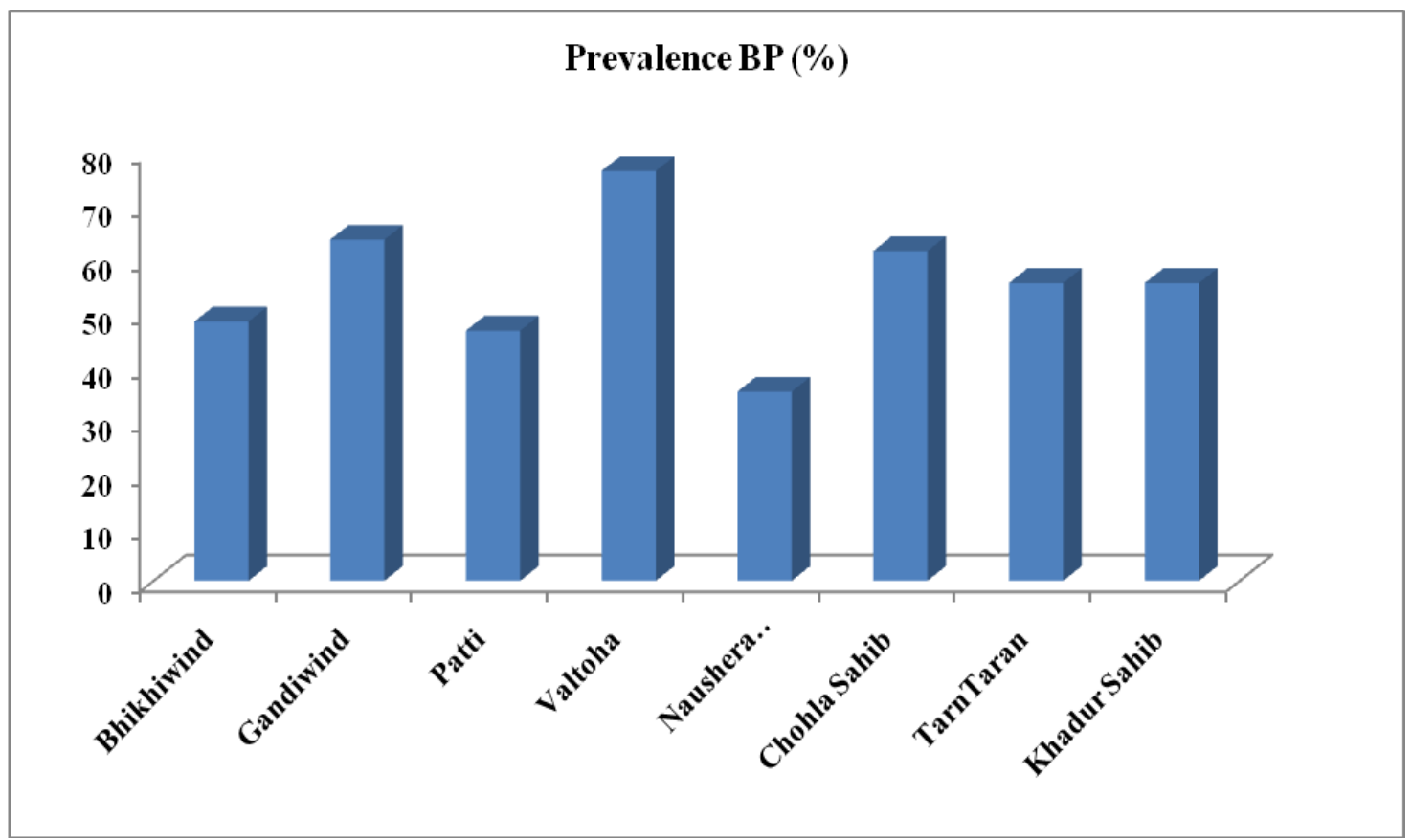

Fig.2 Prevalence of Black Point infection in different blocks of Tarn Taran district of Punjab

The varieties namely PBW 677, PBW 658 and PBW 752 gave resistant reaction in all the blocks of the district. The only variety $\mathrm{WH}$ 1105 was found to be susceptible in the samples collected from Tarn Taran and
Khadur Sahib blocks. In comparison to other varieties i.e HD 3086, HD 2967 which were showing susceptible reaction from all the blocks of the District. The fact that disease development is directly related to varietal 
susceptibility and favourable weather conditions prevailing at heading stage of the crop was also synchronized (Aujla et al., 1986, 1987, Sharma et al., 1998, Kaur et al., 2018).

Overall, it was depicted that farmers would be given guidance so that they cultivate only recommended varieties of the Wheat grown in particular zone of the Punjab. In future the regular surveys should be conducted so, that disease free zone should be identified and declared for the benefits of the farmers.

Farmers would be made aware about the forewarning of the environmental conditions so that they can adopt well in advance management strategies.

\section{References}

Aasma, Zakria M, Asad S, Jamal A, Fayyaz, M, Atiq-ur-Rehman R, Munir, A, Iftikhar, S, Ahmad, Y.(2012). Morpholical and physiological characterization of Tilletia indica isolates from Punjab and Khyber pakhtunkhwa. Pak. J. Phytopathol 24, 106111.

Anonymous (2019) Package of practices for crops of Punjab for Rabi 2019-20. Punjab Agricultural University, Ludhiana. pp. 119.

Aujla S. S., Sharma I, Gill K. S. and Grewal A. S, (1986). Prevalence of Karnal Bunt in Punjab as influenced by varietal susceptibility and meteorological factors. Pl Dis Res. 1: 51-55.

Aujla S.S., Sharma Indu and Sharma I. (1987) New host records of Neovossia indica. In Phytopathol, 40: 437.

Aujla S.S., Grewal A.S., Gill K.S. and Sharma I. (1980). Effect of Karnal Bunt on chappati making properties of wheat grains. Crop Improve. 7: 147-149.

Jain S, Jindal M. M and Mohan C (2012). Status of Black Point disease of wheat in Punjab. Pl. Dis. Res. 27 : 28-33.

Joshi L. M., Singh D. V., Srivastava K. D. and Wilcoxson R. D., (1983) Karnal bunt- A minor disease that is now a new threat to wheat. Bot Rev. 43(1): 309-338.

Kaur J, Bala R, Kaur, H, Pannu, P.P.S., Kumar, A and Bhardwaj, S.C. (2018) Current status of wheat diseases in Punjab. Agric. Res. J 55(1):113-116.

Mitra. M (1931). A new bunt on wheat in India. Annals of Applied Biology 18, 178-179.

Sharma I and Sendhil R (2016) Wheat production in India- A decadal synopsis http://www.FnBnews.com.

Sharma I, Bains N. S and Sharma R.C (2012) Resistance in wheat to Karnal Bunt In: Disease Resistance in wheat Sharma I (ed), CAB International, UK, pp 190-220.

Sharma I, Nanda G. S., Kaloty P. K. and Grewal A. S. (1998) Prevalence of Karnal Bunt of wheat in Punjab. Seed Res, 26: 155-160.

Singh, B. B., Aujla, S. S. and. Sharma, I (1993). Integrated management of wheat Karnal bunt. Int. J. Pest Manage. 39: 431-434.

Singh, D.P., Goel, L.B., Kumar J, Sinha V.C., Singh R.K, Sharma Indu, Aujla, S.S., Singh Amerika, Singh K.P., Tiwari, A.N., Beniwal, M.S., Kitrwasra S.S., Singh, D.V. Srivastava K.D, Aggarwal Rashmi and Gupta B.R. (2003). Post-harvest surveys of wheat grains for the presence of Karnal Bunt and Black Point diseases in different agroclimatic zones of India. Indian J. Agric. Res., 37 (4): 264 - 268

Watkin J.E (2005) Black Point disease of wheat. Neb Guide Publ. Institute of Agriculture and Natural resources, Lancoln Extn. University of Nebraska, USA.

\section{How to cite this article:}

Parminder Kaur, Paramjit Singh and Amarjit Singh. 2020. Analysis of Karnal Bunt and Black Point of Wheat in Tarn Taran District of Punjab, India. Int.J.Curr.Microbiol.App.Sci. 9(05): 914-921. doi: https://doi.org/10.20546/ijcmas.2020.905.100 